\title{
Teromba in the Context of Customs, Nature Elements and the Sustainability Challenges
}

Mohamad Luthfi Abdul Rahman, Muhammad Fakhri Jafrey

To Link this Article: http://dx.doi.org/10.6007/IJARBSS/v11-i2/8287

DOI:10.6007/IJARBSS/v11-i2/8287

Received: 16 December 2020, Revised: 13 January 2021, Accepted: 31 January 2021

Published Online: 26 February 2021

In-Text Citation: (Rahman \& Jafrey, 2021)

To Cite this Article: Rahman, M. L. A., \& Jafrey, M. F. (2021). Teromba in the Context of Customs, Nature Elements and the Sustainability Challenges. International Journal of Academic Research in Business and Social Sciences, 11(2), 800-812.

Copyright: @ 2021 The Author(s)

Published by Human Resource Management Academic Research Society (www.hrmars.com)

This article is published under the Creative Commons Attribution (CC BY 4.0) license. Anyone may reproduce, distribute, translate and create derivative works of this article (for both commercial and non-commercial purposes), subject to full attribution to the original publication and authors. The full terms of this license may be seen at: http://creativecommons.org/licences/by/4.0/legalcode

Vol. 11, No. 2, 2021, Pg. $800-812$

Full Terms \& Conditions of access and use can be found at http://hrmars.com/index.php/pages/detail/publication-ethics 


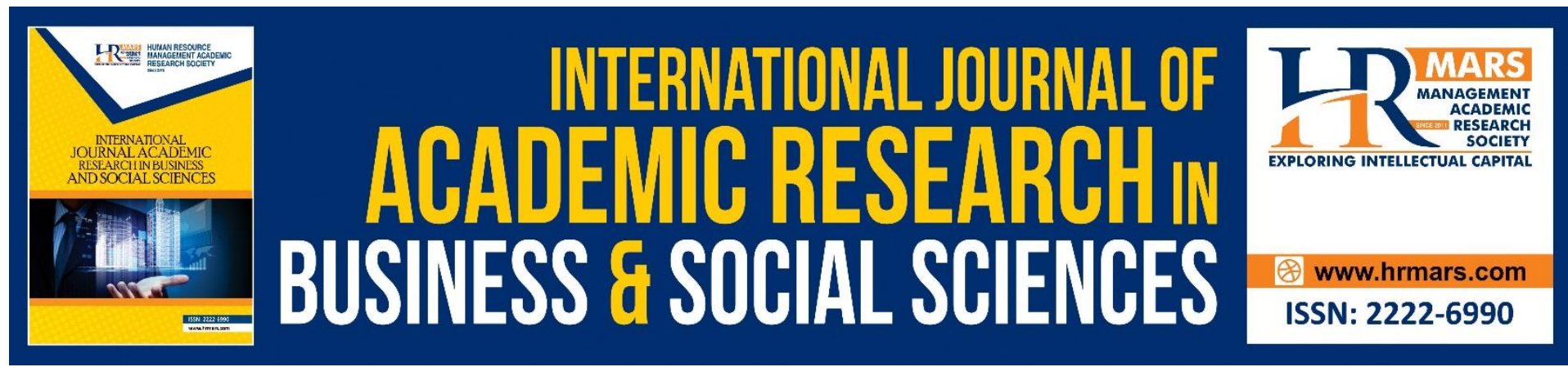

\title{
Teromba in the Context of Customs, Nature Elements and the Sustainability Challenges
}

\author{
Mohamad Luthfi Abdul Rahman, Muhammad Fakhri Jafrey \\ School of Humanities Universiti Sains Malaysia \\ Email: luthfi@usm.my, muhdfakhri970@gmail.com
}

\begin{abstract}
Teromba is one of the traditional Malay poems in Negeri Sembilan, Malaysia. These traditional Malay poems discuss Adat Pepatih that been practices among the community as a lifestyle, particularly in the family aspect. The first objective of this study is to boost up the legacy of teromba in the research framework due to the threat of extinction in the modern era. The second objective is to analyse teromba in the context of family customs that become one of the values of the perpatih community in Negeri Sembilan and the value of beauty contained in this poem. The third objective is to examine the efforts that have made to preserve this poetry in order to remain for a more extended period. The main issue that will be analyzed in this paper is whether Teromba is the only exposure to customs solely or contributes to the values such as the use of natural elements in the creation of this traditional poem? Next issue is whether any efforts had made to ensure that teromba continues to exist throughout the ages? The methodology of this study will use the conceptual framework of cultural studies as a back up to see teromba as one of the crucial elements in the practice of traditional society until modern times. This study will focus on the teromba reversed in writing that has been recorded by a scholar before. Furthermore, the study is significant because it can lift back the legacy of teromba which may be forgotten one day and also able to stifle the importance of teromba in communities that practice Perpatih Customs in Negeri Sembilan.

Keywords: Teromba, Traditional Malay Poems, Customs, Nature, Sustainability
\end{abstract}

\section{Introduction}

Teromba is a heritage communication art of the Minangkabau Malay culture community in Negeri Sembilan, Malaysia which holds firmly to Perpatih custom. Teromba has multiple meaning such as customary perbilangan, law and order, and customs. There are also several terms of teromba given by scholars such as Terasul, Tambo and Salasilah. According to Mat Piah (1989), teromba contains traditional connotations used as guidelines and practices in Perpatih and Temenggung customs until now. The usage of teromba in Perpatih and Temenggung customs is still practised by the Minangkabau society, including some areas in Negeri Sembilan and Melaka.

Meanwhile, Saludin (2007:242) stated that teromba is the composition of customary laws delivered in the form of poetry. Customary law in this context refers to Minangkabau Custom, which is Perpatih Custom or Temenggung Custom that began to be consummate in 
Minangkabau. In Malaysia, only Perpatih custom is practised in Negeri Sembilan and Melaka, especially in Rembau, Kuala Pilah, Tampin, Jelebu and Seremban areas as well as parts of Melaka such as Naning and Alor Gajah areas.

Hussain (1988) stated that teromba is also known as the perbilangan adat which is the bond of free-range poetry that states the customs of institutions or the traditional origins of institutions among those who practice perpatih customs. Therefore, the teromba is a lineage, law, rules and custom that act as guides and practices of the Perpatih custom community in everyday life. However, teromba, which is known by various terms such as terasul, tambo and perbilangan adat has the same meaning. Mat Piah (1989) emphasize the perbilangan adat, customary words, terasul and tambo referring to a form, more appropriately known as teromba. Therefore, teromba still refers to the lineage, rules and customary law, along with variations of the appropriate name according to the place, context and function, namely teromba, terasul, tambo, perbilangan adat, and traditional proverbs.

Teromba has the characteristics of a Malay traditional poem. According to Hussain (1988), teromba is an independent poem that does not determine the number of lines, expressions, rhymes, and words in one line. In this context, the teromba can consist of two, three, four or perhaps dozens of rows which dependent on the title disclose. The form of teromba construction also consists of a combination of diversity of other types of traditional poetry such as syair, pantun, peribahasa, gurindam and other traditional poems in each stanza.

\section{Objective and the Problem Statement}

This study has three main objectives. The first objective is to introduce a literary work in the form of poetry known as teromba, which is renowned in one of the states in Malaysia. The second objective is to study the key elements that exist in the teromba. The third objective is to analyse the government's initiatives to ensure that this teromba poetry's legacy remains for a more extended period of time.

Several problem statements would be addressed in this article. Usually, a literary work is often seen as a story or verses of poetry that only intends to provide entertainment. However, is this teromba also has such a trait? Or does this teromba have more essential aspects of usage in the society's life? Therefore, this article will describe in depth that how teromba is able to elaborate regarding the customs and rules in the life of a society. Moreover, this article will clarify whether the teromba also has elements of nature's beauty in its phrases to showcase the splendours to the readers? Finally, this article also tries to prove whether this poetry's legacy is still well preserved and whether the government has attempted to preserve the poetry for future generations. This study's problem statements are very curial to be explained to prove that the poetry of teromba is a tremendous and distinguished poem in Negeri Sembilan, Malaysia.

\section{Methodology of the Research}

This study is a combination of text studies method and fieldwork. In the text study, there are few texts of the teromba have been collected and analysed in depth to find out the actual contents of teromba. The text study also aims to look at the natural elements used by the author, so that the teromba has a value of beauty when it has been read and heard by readers. The teromba texts selected are the teromba collected and rewritten by the teromba scholars who are well known and authoritative figures in the Negeri Sembilan. 
Furthermore, fieldwork was conducted while writing this article. Fieldwork was conducted in the Rembau District, Jelebu District and Seremban District in Negeri Sembilan. The focus of fieldwork is in several museums. The purpose is to look upon how these teromba are stored and exhibited to the public. This matter should be taken note of because it determines whether the teromba can be sustained towards the future.

\section{Research Gap}

The study of Teromba has been done by several researchers before. The book was written by Saludin (2007) entitled Anjung Teromba describes the definition and characteristics of teromba as a traditional poem. This book also makes comparisons between teromba and spells involving aspects of thought and language style that exist in both of these traditional poems. The results showed that Malay society had high thought and intellectualism. Fadila (2010), in her study entitled Teromba: Wadah Manifestasi Falsafah Melayu in Undergraduate Thesis at Universiti Kebangsaan Malaysia, revealed that Malay philosophy manifested through teromba as oral poetry. Teromba has a role in conveying the thoughts, feeling and it also an art of communication involving community groups. (Jaafar, Aman, and Mat Awal, 2017) entitled "Aspek Kesejajaran dalam Perbilangan Adat Berdasarkan Analisis Stalistik" in Jurnal Akademia. Perbilangan adat has been analyzed involving aspects of language style and impressions displayed in perbilangan adat. Jafrey (2019), in his thesis, has also studied about teromba in Kuala Pilah District, Negeri Sembilan, Malaysia. His study focused on teromba as exposure to family customs and also the comparison of customs contained in teromba with the actual customs recorded in other materials in the district.

Based on the studies that have been done, there are gaps in the research that other researchers have not explored before. So, this paper presents a different focus. This paper will prove that Teromba is not only about a description of the custom, but also its authors pay attention to the elements of aesthetic found in a teromba. Teromba is exquisiteness in terms of shape and also with natural elements included as a comparison or analogy in the concerning teromba. Furthermore, this paper also will attempt to describe the extent that teromba can become the pride of Malay society in Negeri Sembilan which can be last long period and what efforts have made to preserve the teromba poetry? For find the solution in these problems and issues, this paper has used several appropriate study methodologies. The first is the method of text study. This study uses several teromba that have been booked by well-known and authoritative researchers. Secondly, field study methods were conducted at several museums in Negeri Sembilan, Malaysia. This field study aims to see how this teromba is sustained in the state.

\section{Conceptual Framework}

The discussion about teromba is closely related to the concept of culture. It is because teromba is one of the unique cultural practices found in Negeri Sembilan, Malaysia. Tylor (1974) defines the cultural concept as something complex encompasses the knowledge, beliefs, arts, morals, laws, customs and any abilities and habits acquired by a person as a member of society. Culture is a mixture of various aspects of human life that is interconnected in shaping culture in society. Therefore, culture is a complex encompassing various fields and disciplines of knowledge at the same time. Community members will be able to master the culture through learning or socialization process with other members of society because the culture does not exist naturally in a member of that community. 
Endraswara (2006) states that culture comes from the Latin word cultura, which carries the intention of nurturing, cultivating and working. Culture is a comprehensive substance in various fields involving the role of human beings to maintain, cultivate and work on various things in producing culture. Besides, Endraswara (2006) has detailed again that "culture" as a whole of complicated human life includes law, art, morals, customs, and all other efficiencies obtained as members of society. Therefore, culture covers all aspects of the interconnected human way of life obtained through dissemination through social interaction or learning from other members of society. Also, culture must be studied because all forms of behaviour, treatment, customs that become members of society are not natural forms in a person but must be studied in order to be absorbed into themselves.

Based on the framework of cultural concepts written by Tylor (1974) and Endaswara (2006), it was found to be very appropriate with this paper because it is indeed researching teromba which is closely related to the customs. Also, that becomes the principle of communal belief, has an artistic value that is related to the rhythm and use of natural artistic elements and also related to cultural maintenance because this paper also focuses on efforts to preserve the teromba in Negeri Sembilan present period.

\title{
Analysis and Findings
}

Teromba as a Family Custom of Negeri Sembilan Society

The analysis will include customs in family roles, marital customs, divorce customs and property distribution. Married couples with children need to be responsible for raising children from the moment of birth until they reach adulthood. It as stated in the teromba as follows:

\author{
Lama-kelamaan mengadakan anak, \\ Menangis diberikan susu, \\ Dianduh, dibuai, didodoi, diandai, \\ Lapar disuapkan nasi.
}

(Saludin's collection, 2007)

The above quote shows the responsibility of the parents beginning when the child is born. This responsibility starts at the time of their child's birth by providing the necessity for children such as milk and clothing. Child care should be given precisely because the child needs attention and affection from the parents in life. Therefore, parents should pay full attention to every matter involving their child. The responsibility of the parents will continue by sending the child to acquire knowledge after reaching puberty stage.

Children who have reached puberty will send to gain knowledge for the beneficial usage in life. The lessons must be in aligned with the gender and character of the child. It as stated in the teromba as follows:

Bila besar sampai baligh,

Kok lelaki dihantar mengaji,

Sehinggalah tamat,

Lalu dibuat kenduri,

Kok perempuan dihantarkan menganyam dan

menjahit,

Dapat sumpit sebuah,

Dan bantal sebuah. 
(Saludin's collection, 2007)

Based on the teromba, parents have a responsibility to send children to obtain education when they reach puberty. Sons will be sent to learn religious knowledge to distinguish good and bad things as well as avoid doing things contrary to Islamic teachings. Upon completion of the study, the family will hold a feast to celebrate the success of their child who has completed their education. On the other hand, daughters will be sent to get an education in the field of sewing and weaving by the personality of the woman who will be wife and mother in a family. The success of girls in seeking knowledge can be assessed through the results of learning, such as successfully producing pillows and sumpit. Therefore, the responsibility of parents in providing education to their children is essential in shaping their child's personality. Children who have reached adulthood will have the desire to get married.

Children who have grown up and mastered the knowledge that can be used in life will be called upon luck in finding a soul mate. This as described in the teromba as follows:

Setelah itu diserukan pula untungnya,

Diserukan pula tuahnya.

(Saludin's collection, 2007)

Teromba above describes the luck and fortune of a child who has reached adulthood. It can be seen in the statement that the line 'diserukan tuah dan untung' meaning ('summon for luck and profit') in the above verse has meant that the son or daughter will be asked for facilities to get their respective life partner. If a son expresses a desire to be married to his parents, then the parents will try to find a suitable wife for their child. For the daughter, she will wait for luck to investigated by the family of the man who wants to find a wife. From this angle, parents have a responsibility to find the best life partner for their child. Choosing the right match will guarantee the future of their children.

Thus, in the role of parents, parents demonstrate the responsibility that covers three aspects such as childcare, child education and matchmaking. These three aspects require the responsibility of parents to ensure that their children future is assured.

When discussing family customs, the aspect of marriage is also one of the very crucial aspects. The teromba in Negeri Sembilan also describes regarding marriage. In perpatih custom, marriages involving men and women from the same tribe are strictly forbidden. Teromba describes the prohibition of marriage involving couples from the same tribe as follows:

$$
\begin{aligned}
& \text { Celaka, derhaka, } \\
& \text { Dahaga, dahagi, } \\
& \text { Meruntuhkan langit, } \\
& \text { Merebahkan tombak, } \\
& \text { Menguncupkan payung. }
\end{aligned}
$$

(Saludin's collection, 2007)

Endogamy is strictly forbidden because it is against the norms of the Perpatih custom community. Teromba above explains that behaviour involving same tribe marriage is a terrible 
act and is a rebellion committed by members of a tribe who dare to violate the customs that have been practised since the time of the ancestors. Marriages involving couples from the same tribe are considered incest because the couple's relationship is considered siblings. It is because the members of a tribe come from the same ancestors. Moreover, inter-tribal marriage will harm the couple. The depraved effects will be that the woman will lose the right to inherit the inheritance from the family, while the son will also lose the right to be the heir to the customary position in his tribe. Besides, there is a belief that same tribe marriage will bring misfortune to the unborn child. It is supported by Selat (1976) who stated that the punishment of a tribal marriage causes a child born as a result of marriage to be deformed, insufficient in nature, stupid and so on. Intermarriage between tribes is strictly forbidden in Perpatih custom because it causes accidents and destructive effects to the couple for life. Therefore, Perpatih custom encourages marriages involving couples from other tribes.

The ban on same tribe marriage coincides with the cultural principles outlined by Endraswara (2006) as follows:

Budaya merupakan sesuatu yang bersifat normatif yang dianggap sebagai cara dan aturan hidup seperti cita-cita, nilai, tingkah laku dan lain.

Normative is a rule that regulates and controls members of society. With this ban, the community of Perpatih custom will be controlled by not violate the rules and laws that have been set in community. Normative provides punishment and reward as a recognizes to respective behaviour. Marriages that comply with the norm will be rewarded in the nature of recognition in the community of Perpatih custom to married couples. However, marriages that violate the norm will cause the husband and wife to lose the right to inherit and inherit the tribe position. It can be said that the custom in teromba provides much guidance either in the form of recommendations or in the form of prohibitions that must be obeyed by the community. The poetry of teromba brings the essential things in the life of the community in Negeri Sembilan who practice perpatih custom.

The Aesthetic of Shapes and Elements of Nature in Teromba

Although the teromba conveys customs that are considered severe and vital, it does not mean that the teromba only exists as mere legal documentation. On the other hand, teromba still has beautiful arty value as well. The method of delivery teromba has a rhythm that exists through the use of words in each line of teromba. Hamid (2001) explains that rhythmic language contains regular and robust rhythm, rhyming expressions are significant, created through a short line arrangement. In teromba rhythm elements exist through the repetition of words that exist in each row of teromba. Word repetition is divided into three such as anaphora, response and assonance. According to Shaari (1993), anaphora is the repetition of words at the beginning of a line. Examples of teromba lines that have anaphora elements are as follows:

Tak lekang dek panas,

Tak kuning dek kunyit,

Tak lemak dek santan,

Tak haus dek masa.

(Saludin's collection, 2007) 
The teromba above shows the repetition of the word at the beginning of the line. Repetition of the word 'tak' at the beginning of each line emphasizes the meaning and artistic of rhythm on each line. The uniformity of the words at the beginning of each line creates the uniformity of intonation in the compound verse. The element of response is a repetition of words in the middle of the line also exists in the teromba. It can be seen in the teromba as below:

$$
\begin{aligned}
& \text { Apalah janji adat, } \\
& \text { Dekat janji tiga hari, } \\
& \text { Jauh janji tujuh hari. }
\end{aligned}
$$

(Saludin's collection, 2007)

Based on the passage above, the element of response exists through the repetition of the word janji in each line indicating uniformity in the stanza above. This uniformity will embody the resulting rhythm of repetition of the same word in the middle of a line. Meanwhile, teromba also contains assonance, which is a repetition of vowel sounds in two or more syllables. Teromba that presents the element of assonance is as follows:

$$
\begin{aligned}
& \text { Yang baik dipakai, } \\
& \text { Yang buruk dibuang. }
\end{aligned}
$$

(Saludin's collection, 2007)

The teromba above shows the repetition of the vowel 'a' in the first row and the repetition of vowel ' $u$ ' in the second row. This repetition of the vowel gives rise to the effect of utterance in terms of subtlety, softness, melody or artistic. Rhythmic elements exist in teromba involving the repetition of words and vowels each line. Therefore, teromba has an element of rhythm in delivery results through repetition of words and vowels, a contrast to Perpatih custom in reality that delivered directly without emphasis to the element of rhythm.

Teromba is also presented in the form of a stanza. The stanza of the teromba is uncertain because it depends on the topic to be conveyed in a teromba. According to Mat Piah (1989), some verses consist of two lines, three, four or maybe dozens of lines depending on the topic being discussed and the function in question. It can be seen through the following teromba:

Sarang labah-labah, Labah-labah atas buluh, Sembah sudah saya sembah, Saya menyusun jari nan sepuluh.

Kok berunding lepas makan, Kok bertanya lepas penat, Berlonjak saya nan bersetumpu, Bercincang saya nak berlandaskan, Dimana tempat saya nak bersetumpu.

Batang dedap di tengah padang, Datang gajah lilitkannya, 
Tengah sedap kita memandang,

Datang Allah ceraikannya,

Awan dah bertiup,

Angin dah berkibar,

Singgah ke darat patah galah dengan beliung,

Singgah ke laut patah galah dengan dayung,

Ikan balik ke lubuk,

Belut balik ke lumpur,

Maka pada hari nan sehari ini,

Saya jemput anak buah saya,

Kalau patah si kayu gading,

Kayu balak akan jadinya,

Kalau kalah si ayam biring,

Ayam galak jadi gantinya.

(Saludin's collection, 2007)

Teromba above is a teromba used in the custom of inviting the wife to husband's death. The teromba has three stanzas but has an uncertain number of a stanza. Stanza one has four lines, stanza has five lines, while the third stanza has sixteen lines. Teromba has a different number of stanza depending on the topic which been delivered. Additionally, teromba is a traditional poem that is free and not bound by specific rules. However, it can be distinguished from other traditional poems because it involves the delivery of customs and regulations.

Teromba also exhibits beauty value through the use of figurative language to convey topics to readers or listeners. Awang (1987) reckon that figurative language is an imaginative language that carries a meaning other than been written. In teromba there is the use of figurative language mostly in the form of proverbs and symbolism. It usually uses natural elements of flora and fauna. Quote in teromba which use proverbs as a metaphor such as:

Masuk kandang kerbau menguak,

Masuk kandang kambing mengembek,

Bagaimana adat di tempat semenda,

Dipakailah,

Lain lubuk, lain ikannya,

Lain padang, lain belalangnya.

(Saludin's collection, 2007)

The quotes above also display the use of proverbs 'lain lubuk lain ikannya, lain padang, lain belalangnya' as a metaphor. This proverb means that each place has a different culture and lifestyle. This proverb is used as a metaphor in the teromba in delivering things indirectly. The elements of nature used, such as buffaloes, pond, and fish, can beautify this teromba when it is broadcast to the community.

Teromba also uses a lexical language style that contains elements of nature associated with the nature of the universe. According to Saludin (2007), the selection and use of this element or image of nature in accordance with its tradition or philosophy and customs. 
Usually, the element of nature is used as an element of artistic in the teromba to describe something. The use of this element of nature can be seen in the following teromba:

\author{
Kalau sirih pulang ke gagang, \\ Kalau pinang pulang ke tampuk, \\ Kalau kerbau pulang ke kandang, \\ Kalau belut pulang ke lumpur.
}

(Nathan \& Winstedt, 1920, Ulu Muar, Kuala

Pilah)

The scholars who created the teromba have a very sharp observation of nature Saludin (2009) states that nature for the community of perpatih custom practitioners is everything, not only as a place of birth, place of death, place of life, and development but also has a philosophical meaning. The choice of words that have natural elements following the customary philosophy that exists through observation, scrutiny and interpretation of the wonders of nature itself.

Challenges and Efforts to Sustain The Teromba in Negeri Sembilan

Referring to the concept of culture given by Endaswara (2006), he emphasized that every culture that exists in a society is necessary to be preserve. In other words, the culture needs to be maintained and defended as well as possible. Thus, the teromba that is part of the culture of the Negeri Sembilan community also necessarily to be defended.

In this issue of teromba, the first challenge encountered is that teromba do not appear in a large corpus or more extensive collection. Teromba is in several books and various articles. Even in the fieldwork, either in office or house of the customary leader did not find a complete collection of teromba in a written set. Therefore, if a researcher wants to find a complete book or special collection of Negeri Sembilan's Teromba to do further study is impossible. Many challenges had to be overcome to collect the Teromba because it exists in several different sources, including oral sources that have not yet been written.

The second challenge to preserve the teromba is that practices performance are not as widespread as the pantun. It is because teromba is quite specific to the community in Negeri Sembilan that practices perpatih custom. It is also quite elite and prestigious as it is sustained among the customary chiefs and certain people only. The purpose of its use also for their customary guide and it is not easy to make as a leisure show. Therefore, the teromba is quite challenging to make such a pantun which use massively and can be presented casually with entertainment in competitions, etc. The younger generation may be more susceptible to pantun than the teromba are more elite in nature.

However, this does not mean that the teromba is left behind or get extinct without any efforts to sustain it. In fieldwork which as to be done by the researcher, several parties have made various efforts to ensure that the teromba is closer to society today. This effort is carried out at both individual and government levels in Negeri Sembilan.

Efforts to preserve the teromba have been carried out diligently by a scholar and researcher, Datuk Paduka Dr Mohd Rosli Saludin. He has tried to collect teromba from several 
districts in Negeri Sembilan. He rewrote the teromba in the form of a book with his analysis. He has produced more than ten books and papers related to teromba. This paper has also used the teromba that he has booked for analysis. However, Rosli Saludin has not yet produced an extensive and complete collection of the entire Negeri Sembilan's teromba. In addition to collecting teromba in the form of writing, Rosli Saludin also promotes teromba in the form of YouTube performances. There are many YouTube videos that he uploaded for today's young generation viewing. Indirectly the teromba will continue to be known through such new media.

Museums in Negeri Sembilan are also taking active steps to preserve this teromba. Among the efforts made is to display this teromba in the museum gallery. This effort is significant because local or outside visitors to Negeri Sembilan will have the opportunity to see the shape of this teromba and be able to read it while at the museum. The beautifully printed teromba also showcase the greatness and artistic of the teromba. In fieldwork conducted, three museums had made an effort, such as the Customs Museum in Jelebu, Negeri Sembilan, Rembau District Museum and State Museum in Seremban in Negeri Sembilan. To make a legacy prevail to society, which needs to be brought to society. The museum has indeed brought closer to the community through exhibits like this.

\section{Conclusion}

Teromba is a traditional poem that is very special to the community in Negeri Sembilan, Malaysia. Teromba is not merely a poem that aims to provide entertainment alone but brings essential things that are customs and rules of life in a society that practice the customs of perpatih in the state. All the guidelines and prohibitions are in the teromba that are still being observed till today.

However, even though teromba is such a way it still exists as a work of traditional literature. As is well known, literary emphasise great importance to the value of art and beauty in each of its works. Teromba is no exception. Teromba also has the value of artistic through a stanza form arranged neatly and also the use of artistic languages such as the work of other literary work. Teromba also uses natural elements of flora and fauna as a comparison to convey these customs. Indirectly it can be said that teromba is not just a description of customs and regulations solely but has a beautiful way of delivery.

Teromba is also challenged by elements of modernity in this period. Teromba is a very high risk of extinction and is forgotten by the younger generation. It is feared that the younger generation is no longer interested in the teromba, let alone to understand the contents of the teromba. However, the efforts made by specific individuals to maintain this teromba in order to remain sustainable is a reasonable effort. Modern technologies such as YouTube have been used to keep teromba up to date. The efforts of the museum will also certainly succeed in keeping this teromba in the knowledge of the present and future generations. Therefore, the special features of Negeri Sembilan's teromba will continue to be remembered.

\section{Acknowledgment}

Article based on Bridging Incentive Grant (Universiti Sains Malaysia) entitled "Motif Alam dalam Teromba" Motives of Nature in Teromba (304.PHUMANITI.6316407) lead by Dr. Mohamad Luthfi Abdul Rahman, Universiti Sains Malaysia. 


\section{References}

Awang, H. (1987). Glosari Mini Kesusasteraan. Petaling Jaya: Penerbit Fajar Bakti Sdn Bhd.

Endaswara, S. (2006) Penelitian Kebudayaan: Ideologi, Epistemologi dan Aplikasi.. Yogyakarta: Pustaka Widyatama.

Fadila, N. F. (2010). Teromba: Wadah Manifestasi Falsafah Melayu. Masters Thesis. Unpublished. Universiti Kebangsaan Malaysia, Bangi.

Hamid, I. (2001). Perkembangan Kesusasteraan Melayu Lama. Petaling Jaya: Pearson Education Malaysia.

Hussain, S. (1988). Glosari Istilah Kesusasteraan. Kuala Lumpur: Dewan Bahasa dan Pustaka.

Jaafar, M. F., Aman, I., \& Mat Awal, N. (2017). "Aspek Kesejajaran dalam Perbilangan Adat Berdasarkan Analisis Statistik". In Jurnal Akademia, 87(1), 279-290.

Jafrey, M. F. (2019). Teromba Kekeluargaan Adat Perpatih Negeri Sembilan: Satu Kajian Budaya. Masters Disertation (mix mode), Unpublished. Universiti Sains Malaysia.

Mat Piah, H. (1989). Puisi Melayu Tradisional. Kuala Lumpur: Dewan Bahasa dan Pustaka.

Nathan, J. E., \& Winstedt, R. O. (1920). Johol, Inas, Ulu Muar, Jempul, Gunong Pasir and Terachi: Their History and Constitution. London: Luzac \& Co.

Saludin, M. R. (2007). Anjung Teromba. Bukit Mertajam: Goal Intelligent Publishing Sdn Bhd.

Saludin, M. R. (2009). Teromba dalam Puisi Melayu Tradisional. Shah Alam: Karisma Publications Sdn Bhd.

Selat, N. (1976). Sistem Sosial Adat Perpatih. Kuala Lumpur: Utusan Melayu.

Shaari, R. (1993). Memahami Gaya Bahasa. Kuala Lumpur: Dewan Bahasa dan Pustaka.

Tylor, E. B. (1974). Primitive Culture. New York: Gordion Press. 


\section{Attachments}

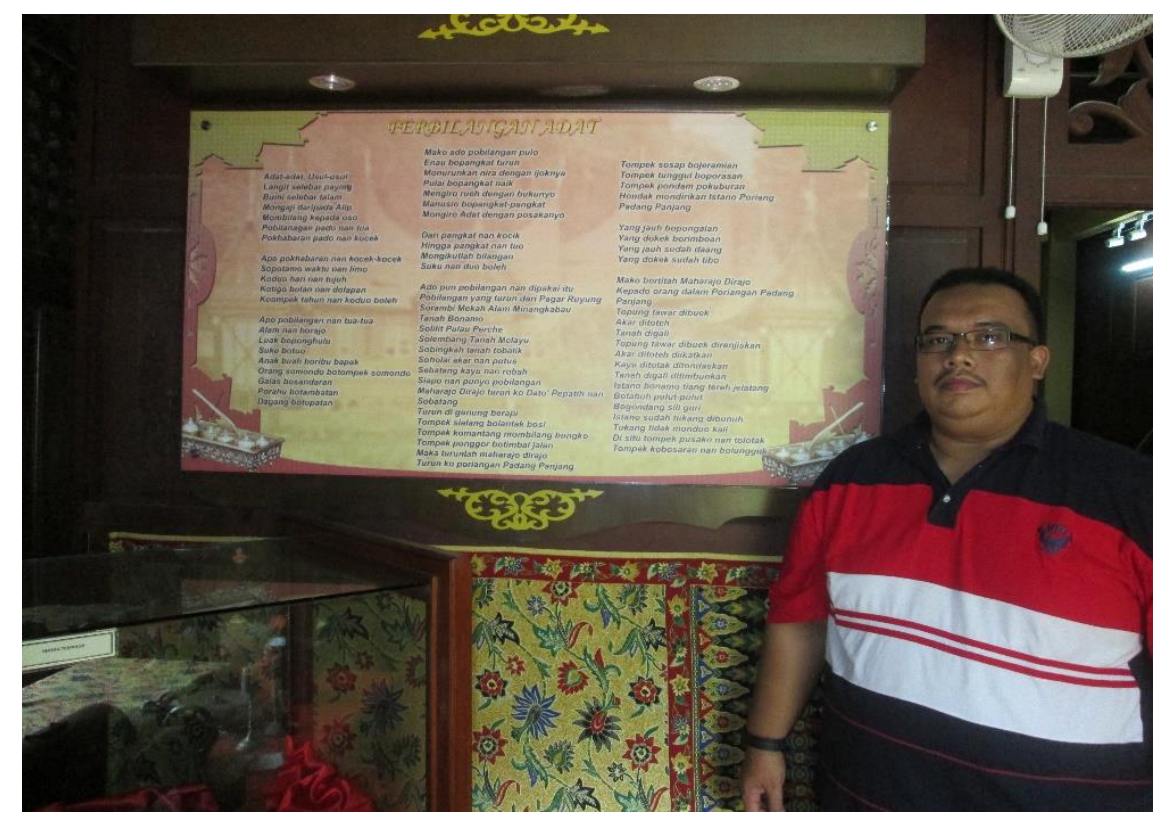

Photo 1: The researcher stands beside the printed verse of teromba in Rembau Museum in Negeri Sembilan, Malaysia.

Photo Sources: Researcher's personal collection.

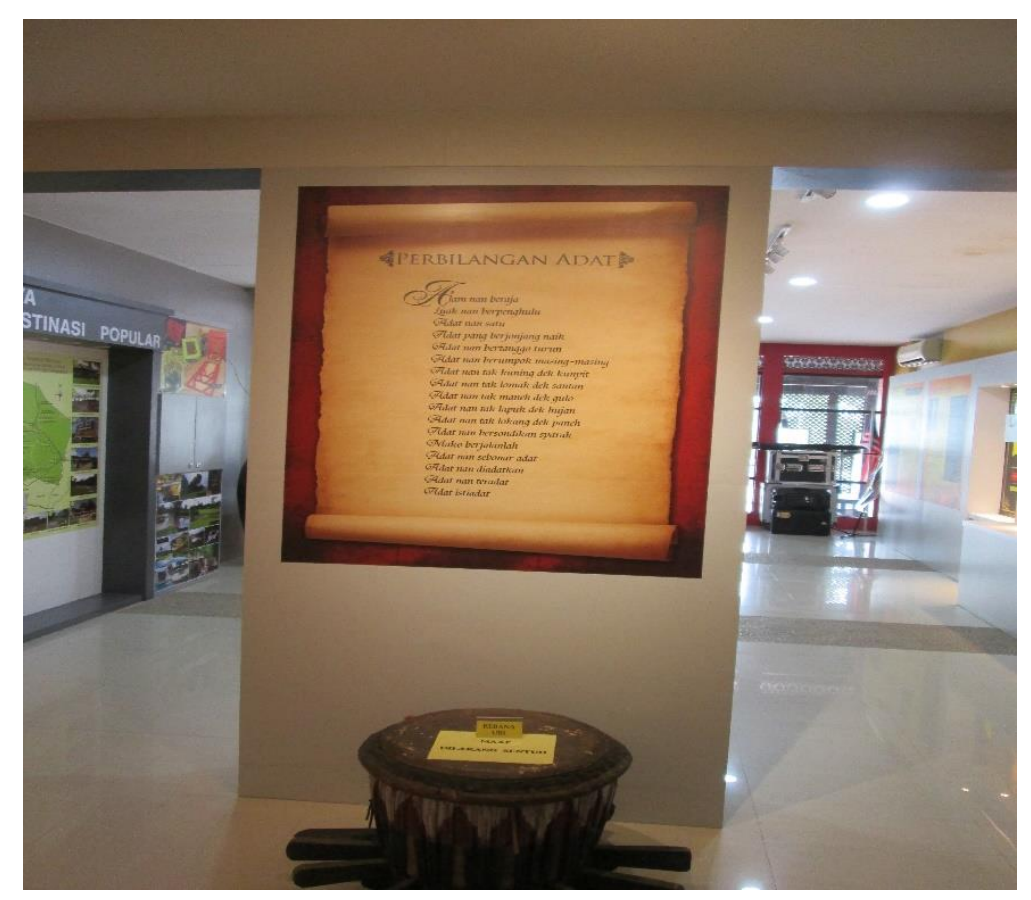

Photo 2: The verse of teromba also displayed in Negeri Sembilan State Museum. Photo Sources: Researcher's personal collection. 